\title{
Immunocytochemical and quantitative study of actin, desmin and vimentin in the peritubular cells of the testes from elderly men
}

\author{
M. I. Arenas ${ }^{1}$, F. R. Bethencourt ${ }^{2}$, M. P. De Miguel ${ }^{1}$, B. Fraile ${ }^{1}$, \\ E. Romo ${ }^{1}$ and R. Paniagua ${ }^{1 *}$ \\ ${ }^{1}$ Department of Cell Biology and Genetics, University of Alcalá, E-28872 Alcalá de Henares (Madrid), \\ Spain; and ${ }^{2}$ Department of Urology. Hospital Principe de Asturias, E-28872 Alcalá de Henares (Madrid), \\ Spain
}

\begin{abstract}
A quantitative immunohistochemical study using light and electron microscopy was carried out to evaluate the morphological and quantitative distribution of the peritubular cells that immunoreact with actin, vimentin and desmin, alone or in combinations, in normal adult testes and the changes in these cells in elderly men. Seminiferous tubules in ageing testes were classified in three groups according to the degree of lamina propria thickening due to tubular sclerosis: group I, $<8 \mu \mathrm{m}$; group II, 8.1-12 $\mu \mathrm{m}$; and group III, $>12.1 \mu \mathrm{m}$. The number of peritubular cells per cross-sectioned tubule increased from group I to group III tubules. However, no significant differences between ageing men and controls were found in the total number of peritubular cells per testis. Most peritubular cells of control testes and of group I and group II tubules displayed immunoreactivity to actin. The peritubular cells in the outermost layers of group III tubules showed no or scanty reaction. The number of actin-immunostained cells per cross-sectioned tubule decreased $(P<0.05)$ with tubular sclerosis. The total number of these cells per testis was significantly lower $(P<0.05)$ in elderly men. A narrow band around the seminiferous epithelium immunostained for desmin in control testes and group I tubules. These cells also immunoreacted to actin and vimentin. In group II and, principally, in group III tubules, only isolated peritubular cells were immunostained for desmin. The number of desmin-immunostained cells per cross-sectioned tubule decreased with tubular sclerosis and the total number per testis was also lower in elderly men. Vimentin immunostaining was observed in most peritubular cells in all tubule groups; these cells also immunoreacted to actin. Vimentin and desmin co-localized only in the inner peritubular cell layers. The number of vimentin-immunostained cells per cross-sectioned tubule increased with the degree of tubular sclerosis but the total number of these cells per testis did not differ significantly between control and ageing testes.
\end{abstract}

\section{Introduction}

The lamina propria or tunica propria that surrounds the seminiferous epithelium in the human testis is about $7 \mu \mathrm{m}$ thick. It consists of a multilayered basal lamina and, externally to it, 3-7 layers of flattened, elongated peritubular cells intermingled with microfibrils, collagen and elastic fibres (de Kretser et al., 1975; Bustos-Obregón, 1976). The peritubular cells forming the 3-5 innermost layers of the lamina propria display the ultrastructural characteristics of myoid cells (myofibroblasts), including numerous cytoplasmic filaments and electron-dense zones (for review, see Maekawa et al., 1996). In the human adult testis, these cells immunoreact intensely to pan-actin (Martín et al., 1992; Santamaría et al., 1992), smooth muscle $\alpha$-actin (Holstein et al., 1996), an antigen that is closely related

${ }^{*}$ Correspondence and reprint requests.

Revised manuscript received 30 October 1996 to smooth muscle $\gamma$-actin and that is detected with the GB42 antibody (Kohnen et al., 1995), smooth muscle $\alpha$-myosin (Longtine et al., 1985; Holstein et al., 1996), desmin and vimentin (Davidoff et al., 1990; Holstein et al., 1996), although the variability in both the expression of these antigens and filament distribution suggest different phenotypes of myofibroblasts (Holstein $e$ al., 1996). The peritubular cells forming the two outermost cell layers are fibroblasts that immunostain to vimentin but not to desmin (Davidoff et al., 1990; Martín et al., 1992; Santamaría et al., 1992).

In many testicular disorders associated with germ-cell depletion, the tubular diameter decreases while the tubular lamina propria undergoes a progressive enlargement that ends in a complete tubular sclerosis (hyalinization) (Söderström, 1986). In some testicular disorders showing tubular sclerosis, such as Klinefelter's syndrome (Martín $e t$ al., 1992) and varicocele (Santamaría et al., 1992), the number of desmin-positive cells and their immunostained content per 

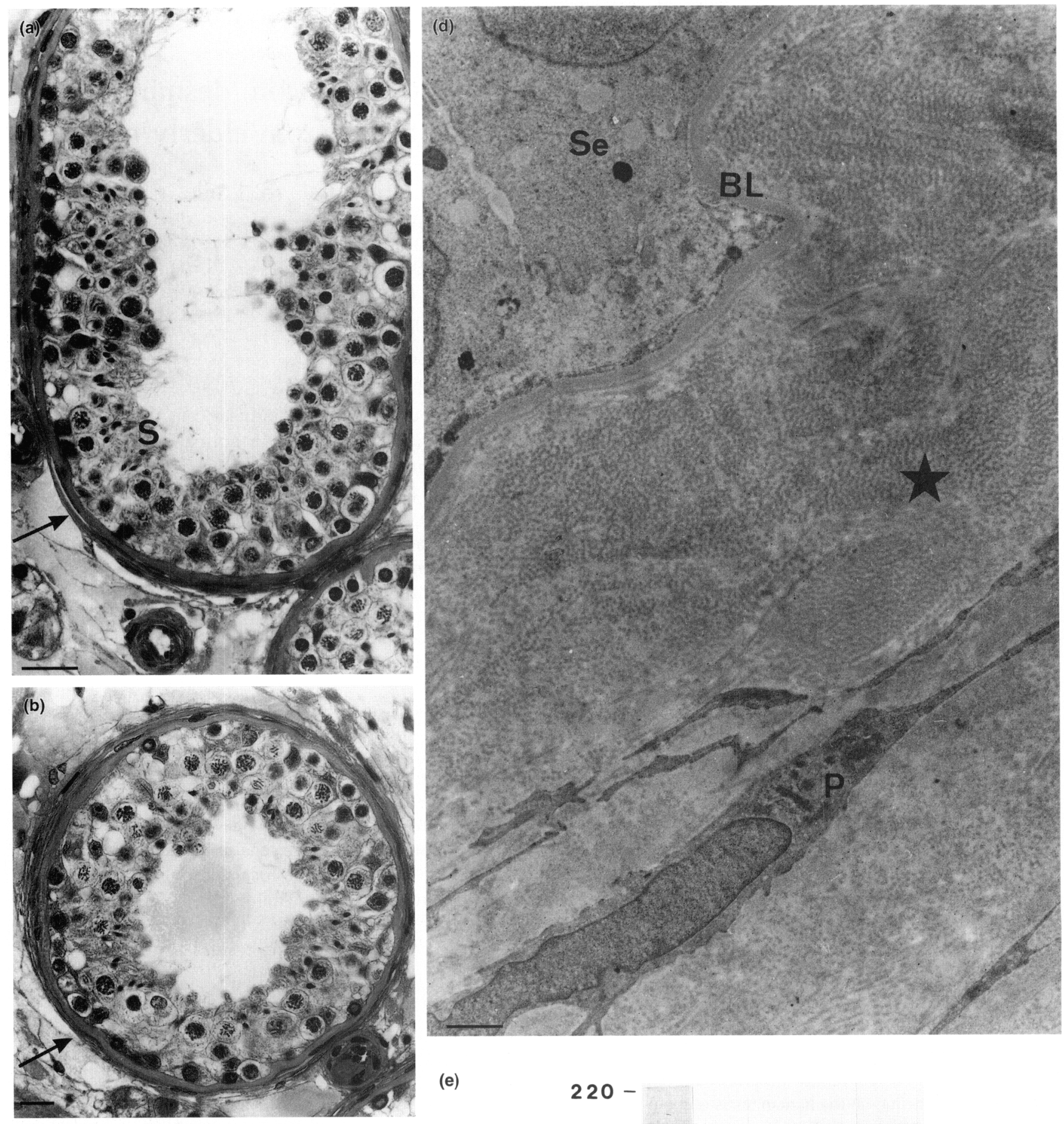

(e)
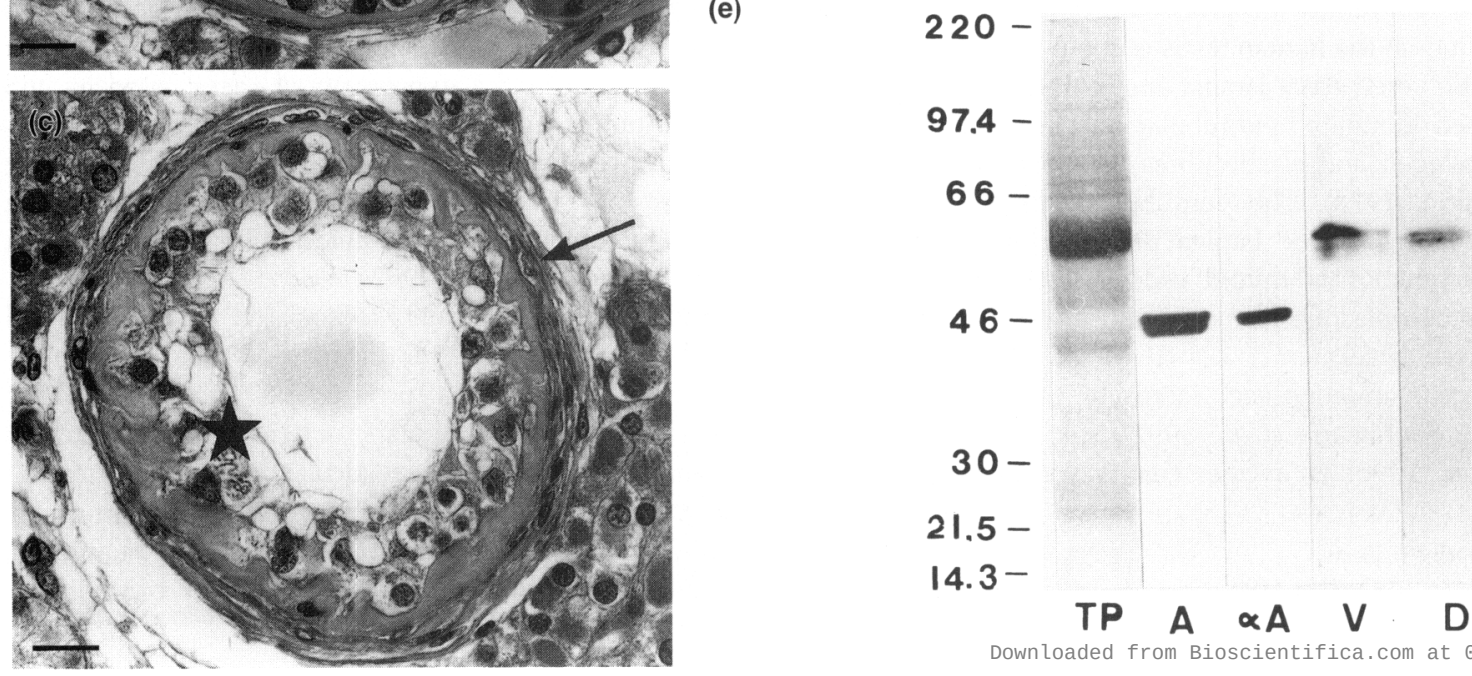

$21.5-$

14.3-

TP $A \propto A \quad V \quad D$

Downloaded from Bioscientifica.com at $04 / 26 / 2023$ 08:42:47AM 
cross-sectioned tubule also decreases with advancing tubular sclerosis but the number and immunostained content of peritubular vimentin-positive cells increases. In other testicular disorders involving tubular sclerosis, the number of peritubular cells per cross-sectioned tubule either increases, as in excretory duct obstruction and as seen after some several hormone treatments (Sapino ef al., 1987; Decensi et al., 1989), or remains unchanged, as in cryptorchidism (Paniagua et al., 1990); however, no distinction between desmin-positive and vimentinpositive peritubular cells was made in these reports. With respect to the literature, the alterations in peritubular cells are not necessarily the same in all testicular disorders involving tubular sclerosis, and quantitative studies that provide information about changes in the total numbers of both peritubular cell types (that is, desmin-positive and vimentin-positive) per testis in different aetiologies are required.

Germ-cell depletion and tubular sclerosis is also associated with ageing (Johnson, 1986; Paniagua et al., 1987a). Quantitative studies have shown that the total number of peritubular cells per testis remains unchanged with advancing age (Johnson, 1986). In a previous immunohistochemical study on ageing men showing disturbed spermatogenesis, Davidoff $e t$ al. (1990) observed that desmin immunoexpression decreased, at least apparently, in the peritubular cells of the thickened lamina propria, whereas vimentin immunostaining remained unchanged. However, no quantitative histochemical studies that provide information about these changes in immunoexpression in the filaments of peritubular cells have been reported in elderly men. The aim of this study was to determine the morphological and quantitative distribution of the peritubular cells that immunoreact to actin, vimentin or desmin, alone or in combination, in the lamina propria of normal adult testes and the changes in these cells in the testes of elderly men.

\section{Materials and Methods}

Orchidectomy specimens were obtained, with informed consent, from 21 elderly men (70-80 years old) with prostatic carcinoma who had received no previous hormone or drug treatments and had no testicular, endocrine or related disorders. All had fathered at least one child and had no previous histories of exposure to toxic agents.

Testicular specimens were processed for western blotting analyses and for light and electron microscope immunohistochemical studies. The primary monoclonal antibodies used were: (1) antibody to chick actin (Amersham, Buckinghamshire); (2) antibody to myeloma cell smooth muscle $\alpha$-actin (Sigma, Barcelona); (3) antibody to bovine vimentin (BoehringerMannheim, Mannheim); and (4) antibody to human desmin (Biogenex, San Ramon, CA). All antibodies were derived from mice.

The specificity of primary antibodies was tested in the testes of two of these elderly men using western blot analysis as described by Towbin et al. (1979). Each testis was homogenized in Tris-HCl buffer $\left(0.5 \mathrm{~mol} \mathrm{l}^{-1}, \mathrm{pH} 7.4\right)$ containing $1 \mathrm{mmol}$ EDTA $\mathrm{I}^{-1}, 12 \mathrm{mmol} 2$-mercaptoethanol $\mathrm{l}^{-1}$ and $1 \mathrm{mmol}$ phenylmethylsulfonyl fluoride $1^{-1}$. The homogenate was centrifuged at $10000 \mathrm{~g}$ for $30 \mathrm{~min}$. After boiling for $2 \mathrm{~min}$ at $98^{\circ} \mathrm{C}$, aliquots of $25 \mu \mathrm{g}$ protein were separated in SDSpolyacrylamide $(12 \%, w / v)$ slab minigels. Separated proteins were transferred for $4 \mathrm{~h}$ at $0.25 \mathrm{~A}$ to nitrocellulose paper and, then the nitrocellulose sheets were stained with Ponceau red, soaked in blocking solution ( 1 mol glucose $1^{-1}, 1 \%(\mathrm{w} / \mathrm{v}) \mathrm{BSA}$, $0.5 \%(\mathrm{v} / \mathrm{v})$ Tween-20, 10\% (v/v) glycerol in PBS, pH 7.3) overnight at $37^{\circ} \mathrm{C}$, and then incubated with the primary antibodies (all at 1:1000 dilution in blocking solution) for $3 \mathrm{~h}$. After extensive washing with PBS-Tween-20, the sheets were incubated with a peroxidase-labelled second antibody (goat anti-mouse biotinylated Ig) (BioCell, Cardiff) at 1:3000 dilution in blocking solution. The filters were developed with a chemiluminescence ECL western blotting detection reagent, following the procedure described by the manufacturer (Amersham).

For immunohistochemical and quantitative studies using the light microscope, both testes of 19 elderly men were sliced parallel to the sagittal plane every $8 \mathrm{~mm}$. Some slides were frozen with liquid nitrogen and cut with a cryostat into sections $8 \mu \mathrm{m}$ thick, which were mounted on glycerin-gelatineprecoated slides and fixed for $10 \mathrm{~min}$ with methanol at $-20^{\circ} \mathrm{C}$ and then for $5 \mathrm{~s}$ with absolute acetone. Other slides were fixed for $24 \mathrm{~h}$ at room temperature in $10 \%(\mathrm{v} / \mathrm{v})$ formaldehyde buffered with 0.1 mol phosphate $1^{-1}$, dehydrated, embedded in paraffin wax and cut into sections $6 \mu \mathrm{m}$ thick. Both frozen and paraffin-embedded sections were either stained with haematoxylin-eosin (HE) or processed following the avidinbiotin-peroxidase complex ( $\mathrm{ABC}$ ) method (Hsu et al., 1981). Sections were hydrated (after deparaffinization in paraffinembedded material), incubated for $20 \mathrm{~min}$ in $0.3 \%(\mathrm{v} / \mathrm{v}) \mathrm{H}_{2} \mathrm{O}_{2}$ in PBS to reduce endogenous peroxidase activity and digested with $0.1 \%(\mathrm{w} / \mathrm{v})$ trypsin solution in $\mathrm{CaCl}_{2}\left(0.1 \mathrm{~mol} \mathrm{I}^{-1}\right)$ at $37^{\circ} \mathrm{C}$ for $10 \mathrm{~min}$. Afterwards, the sections were incubated for $2 \mathrm{~h}$ at room temperature with the primary antibody diluted in PBS

\footnotetext{
Fig. 1. (a-c). Seminiferous tubules in sections of testes stained with haematoxylin-eosin. (a) Normal testis of a 34-year-old man showing a normally thickened lamina propria (arrow) and complete spermatogenesis (S, differentiated spermatids). (b) Group I tubule of a 74-year-old man. The lamina propria (arrow) is nearly normal and some differentiated spermatids can be observed. (c) Group III tubule of a 78-year-old man, showing a thickened, hyalinized lamina propria (arrow) and an atrophic seminiferous epithelium ( $\star$ ). (d) Electron micrograph of the lamina propria in a group III tubule of a 72-year-old man. The Sertoli cells (Se) rest on a multilayered basal lamina (BL), which is surrounded by a band of collagen fibres $(\star)$ comprising few cells. Outer to this band, several peritubular cell layers (P), embedded in collagen fibres, can be seen. (e) western blotting in testicular extracts from a 71-year-old man, after electrophoresis on a 12\% SDS-polyacrylamide gel. TP, total protein markers stained with Coomassie blue; $A$, western blot stained with anti-actin antibodies; $\alpha \mathrm{A}$, western blot stained with anti- $\alpha$-smooth muscle actin antibodies; $\mathrm{V}$, western blot stained with anti-vimentin antibodies; $\mathrm{D}$, western blot stained with anti-desmin antibodies. Molecular masses ( $\mathrm{kDa}$ ) are shown on the left. Scale bars represent $(\mathrm{a}, \mathrm{b}, \mathrm{c}) 20 \mu \mathrm{m}$ and (d) $1 \mu \mathrm{m}$. The degree of lamina propria thickening due to tubular sclerosis is $<8 \mu \mathrm{m}$ in group I tubules, $8.1-12.0 \mu \mathrm{m}$ in group II tubules and $>12.1 \mu \mathrm{m}$ in group III tubules.
} 
Table 1. Mean tubular diameter, lamina propria thickness and numbers of peritubular cell types per cross-sectioned seminiferous tubule in young-adult control testes and testes from ageing men

\begin{tabular}{|c|c|c|c|c|c|c|}
\hline \multirow[b]{2}{*}{ Testis type } & \multirow{2}{*}{$\begin{array}{c}\text { Mean } \\
\text { tubular } \\
\text { diameter } \\
(\mu \mathrm{m})\end{array}$} & \multirow{2}{*}{$\begin{array}{c}\text { Lamina } \\
\text { propria } \\
\text { thickness } \\
(\mu \mathrm{m})\end{array}$} & \multirow[b]{2}{*}{$\begin{array}{c}\text { All types } \\
\text { (stained with HE) }\end{array}$} & \multicolumn{3}{|c|}{ Peritubular cell numbers } \\
\hline & & & & $\begin{array}{l}\text { Actin- } \\
\text { positive }\end{array}$ & $\begin{array}{l}\text { Desmin- } \\
\text { positive }\end{array}$ & $\begin{array}{l}\text { Vimentin- } \\
\text { positive }\end{array}$ \\
\hline Controls & $198 \pm 9.7^{a}$ & $7.6 \pm 0.7^{\mathrm{a}}$ & $15.12 \pm 1.2^{\mathrm{a}}$ & $15.31 \pm 1.6^{\mathrm{a}}$ & $11.12 \pm 1.5^{\mathrm{a}}$ & $14.73 \pm 1.4^{\mathrm{a}}$ \\
\hline Ageing men & $167 \pm 10.3^{b}$ & $12.0 \pm 1.7^{\mathrm{b}}$ & $18.78 \pm 2.6^{b}$ & $13.08 \pm 2.2^{b}$ & $9.01 \pm 2.0^{b}$ & $18.65 \pm 2.4^{b}$ \\
\hline Group III tubules & $148 \pm 13.5^{\mathrm{d}}$ & $14.4 \pm 1.2^{\mathrm{d}}$ & $21.05 \pm 2.3^{\mathrm{d}}$ & $12.34 \pm 2.1^{c}$ & $7.83 \pm 2.1^{\mathrm{c}}$ & $20.71 \pm 2.9^{d}$ \\
\hline
\end{tabular}

For each parameter (column), values with different superscript letters are significantly different $(P \leq 0.05)$. For each type of testis, 19 testes were measured. The degree of lamina propria thickening due to tubular sclerosis is $<8 \mu \mathrm{m}$ in group I tubules, $8.1-12.0 \mu \mathrm{m}$ in group II tubules and $>12.1 \mu \mathrm{m}$ in group III tubules. HE, haematoxylin-eosin.

Table 2. Volume and number per pair of testes of peritubular cell nuclei stained with haematoxylin-eosin in young-adult control testes and testes from ageing men

\begin{tabular}{lccccc}
\hline $\begin{array}{l}\text { Testis } \\
\text { type }\end{array}$ & $\begin{array}{c}\text { Testicular } \\
\text { volume } \\
\left(\mathrm{cm}^{3}\right)\end{array}$ & $\begin{array}{c}\text { Volume } \\
\text { density of } \\
\text { nuclei } \\
(\%)\end{array}$ & $\begin{array}{c}\text { Total } \\
\text { nuclear } \\
\text { volume }\end{array}$ & $\begin{array}{c}\text { Average } \\
\text { nuclear } \\
\text { volume } \\
\left(\mu \mathrm{m}^{3}\right)\end{array}$ & $\begin{array}{c}\text { Total } \\
\text { number } \\
\left(\times 10^{\circ}\right)\end{array}$ \\
\hline Controls & $32.20 \pm 3.1^{\mathrm{a}}$ & $0.49 \pm 0.03^{\mathrm{a}}$ & $158 \pm 10.1^{\mathrm{a}}$ & $194 \pm 9.4^{\mathrm{a}}$ & $814 \pm 56^{\mathrm{a}}$ \\
Ageing men & $24.30 \pm 3.4^{\mathrm{b}}$ & $0.63 \pm 0.04^{\mathrm{b}}$ & $152 \pm 14.6^{\mathrm{a}}$ & $198 \pm 9.9^{\mathrm{a}}$ & $762 \pm 77^{\mathrm{a}}$ \\
\hline
\end{tabular}

For each parameter (column), values with different superscript letters are significantly different $(P \leq 0.05)$.

For each type of testis, 19 testes were measured.

containing $1 \%(w / v)$ BSA. The primary antibody dilutions found to be optimal were 1:200 for $\alpha$-actin and actin, and 1:50 for vimentin and desmin. Afterwards, the sections were washed twice in PBS and then incubated with goat anti-mouse biotinylated Ig at 1:400 dilution. After incubating for $\mathrm{Ih}$ with the second antibody, the sections were incubated with $A B C$ and developed with diaminobenzidine $(\mathrm{DAB})$, using the glucose oxidase-DAB-nickel intensification method (Hsu and Soban, 1982). Thereafter, the sections were dehydrated in ethanol and mounted. Some sections were also counterstained with haematoxylin. In some sections, a double immunostaining method to detect actin-desmin, actin-vimentin or desminvimentin in the same section was used: one antigen was detected with the glucose oxidase-DAB-nickel method while the other antigen was detected with the DAB- $\mathrm{H}_{2} \mathrm{O}_{2}$ method, without intensification ( $\mathrm{Hsu}$ and Soban, 1982; Krenács et al., 1990).

For the quantitative study, the volume of testicular parenchyma $\left(V_{\mathrm{T}}\right)$ after fixation, dehydration and embedding was estimated by considering the testis as an ellipsoid. Length $(2 a)$ and width (2b) were measured in the sections through the sagittal plane and transformed into volume $\left(4 \pi a b^{2}\right) / 3$ (Paniagua et al., 1987a). In 12 non-consecutive, randomly selected paraffin wax sections of each testis (three of each of the sections stained for $\mathrm{HE}$, actin, desmin and vimentin), 15 randomly selected microscopic fields $\left(640000 \mu \mathrm{m}^{2}\right)$ were used. The number of microscopic fields in each section necessary for calculations was determined by successive approaches to obtain the minimum number of microscopic fields required to reach the lowest $\mathrm{SD}$. A greater number of microscopic fields than this did not decrease the SD. On each of these fields, the following parameters were calculated: (1) the average thickness of the lamina propria, the mean tubular diameter excluding the lamina propria, and the average number of nuclei of peritubular cells (total, actinpositive, vimentin-positive and desmin-positive cells) per transverse tubular section, on at least ten cross-sectioned tubules from each field; (2) volume density $\left(V_{d}\right)$ of the nuclei of each peritubular cell type; that is, the surface area occupied by the nuclei divided by the total surface area of the field, calculated using an image analyser; (3) the numerical density $\left(N_{d}\right)$ of peritubular cell types, calculated by dividing (for each cell type) $V_{d}$ by the average nuclear volume $\left(V_{n}\right)\left(V_{n}\right.$ was calculated by considering the nuclei as ellipsoids with semiaxes $a$ and $b$, using the formula $V_{n}=\left(4 \pi a b^{2}\right) / 3$; the semiaxes were measured with a vernier ocular); and (4) the total number of each peritubular cell type by multiplying (for each cell type) $N_{d}$ by $V_{\mathrm{T}}$.

Since all testes used in this study showed different degrees of tubular sclerosis, even within the same testis, the seminiferous tubules observed in each testis were classified in three groups (I, II and III) according to the degree of lamina propria thickening, which was usually associated with a progressive degree of hypospermatogenesis. Group I tubules had a lamina propria of normal thickness $(<8 \mu \mathrm{m})$; these tubules presented complete spermatogenesis or, at least, round spermatids. Group 

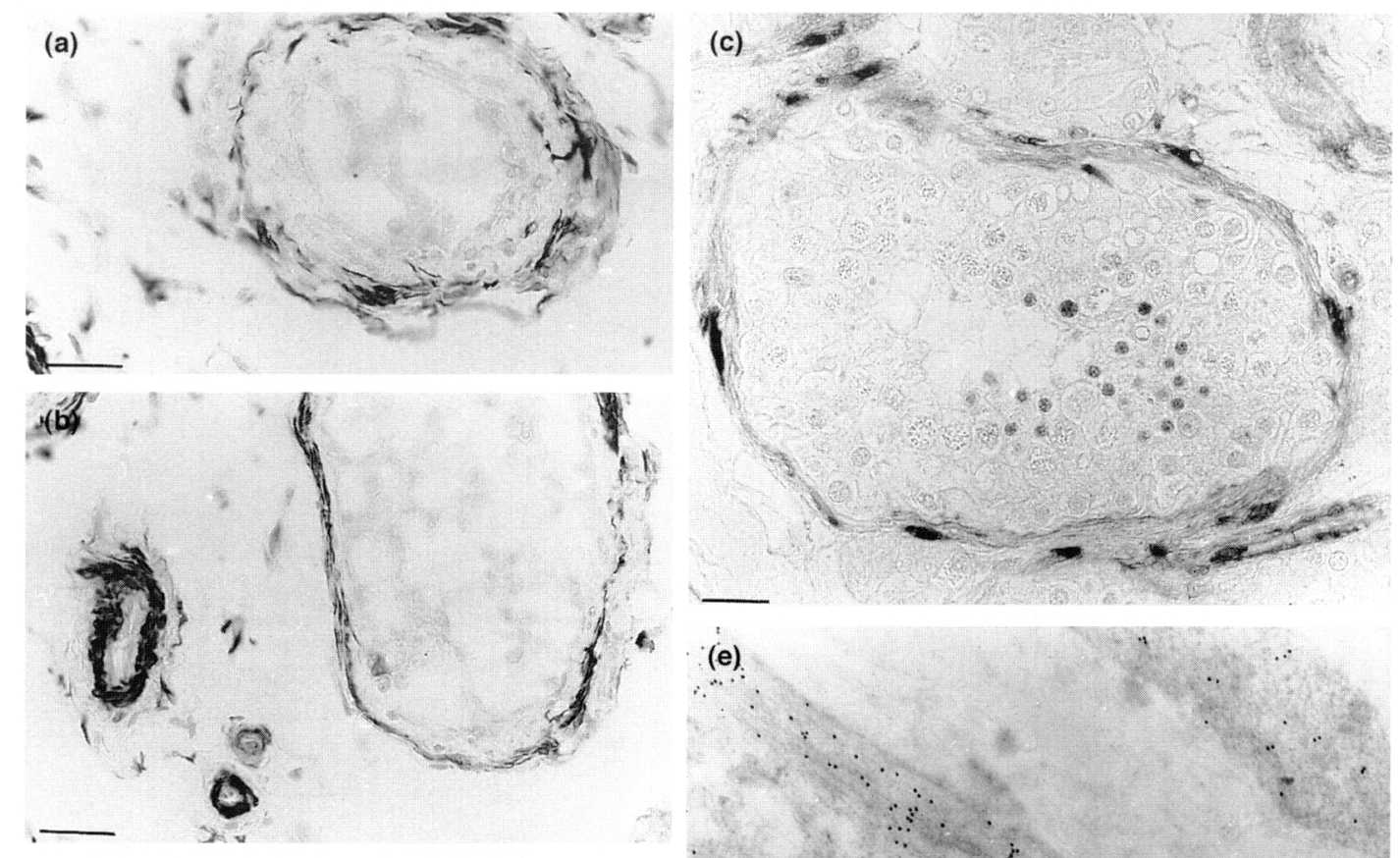

(d)
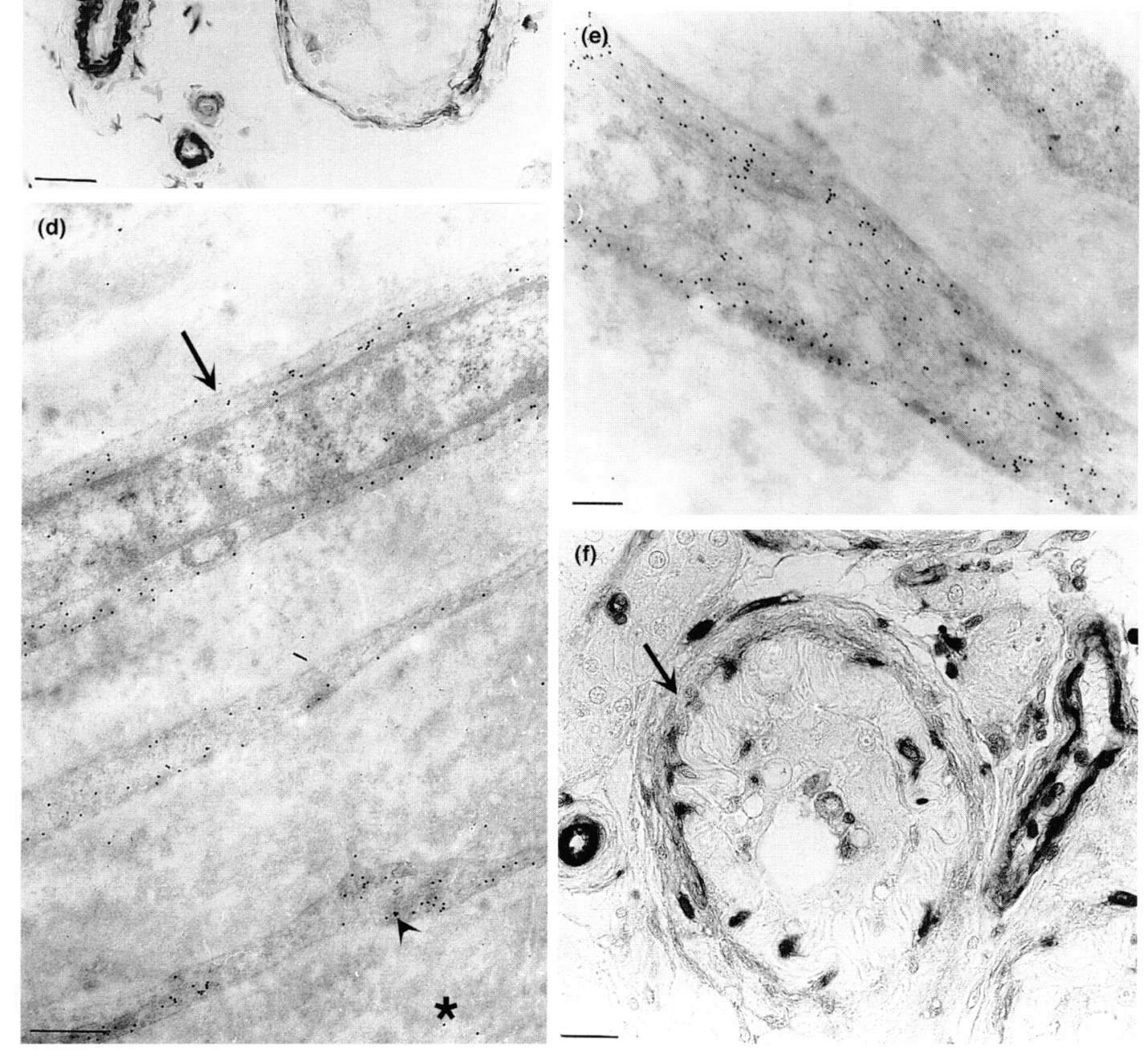

Fig. 2. (a,b) Frozen sections of seminiferous tubules with a thickened lamina propria from the testis of a 77-year-old man. Whereas (a) $\alpha$-smooth muscle actin immunostaining extends throughout the entire thickness of the lamina propria, (b) desmin immunostaining occupies only an inner band of the lamina propria. (c) Group I tubule of a 72-year-old man immunostained to actin; the immunoreaction is a uniform band around the seminiferous tubule. The seminiferous epithelium is weakly immunostained. (d) Electron micrograph of the same testis as in (c) immunolabelled to actin; the immunoreaction is observed in the perinuclear cytoplasm (arrow) and cytoplasmic projections (arrowhead) of most peritubular cells. ( $\star$, collagen fibres). (e) Cytoplasmic projection of a peritubular cell in the same testis as in (c). Actin immunolabelling is principally observed in the microfilament bundles. (f) Group III tubule of a 79-year-old man immunostained to actin. Some cells in the outer layers of the lamina propria are not immunostained (arrow). Scale bars represents (a, b) $30 \mu \mathrm{m},(\mathrm{c}, \mathrm{f}) 20 \mu \mathrm{m}$, (d) $0.5 \mu \mathrm{m}$ and (e) $0.2 \mu \mathrm{m}$. The degree of lamina propria thickening due to tubular sclerosis is $<8 \mu \mathrm{m}$ in group I tubules, $8.1-12.0 \mu \mathrm{m}$ in group II tubules and $>12.1 \mu \mathrm{m}$ in group III tubules. 

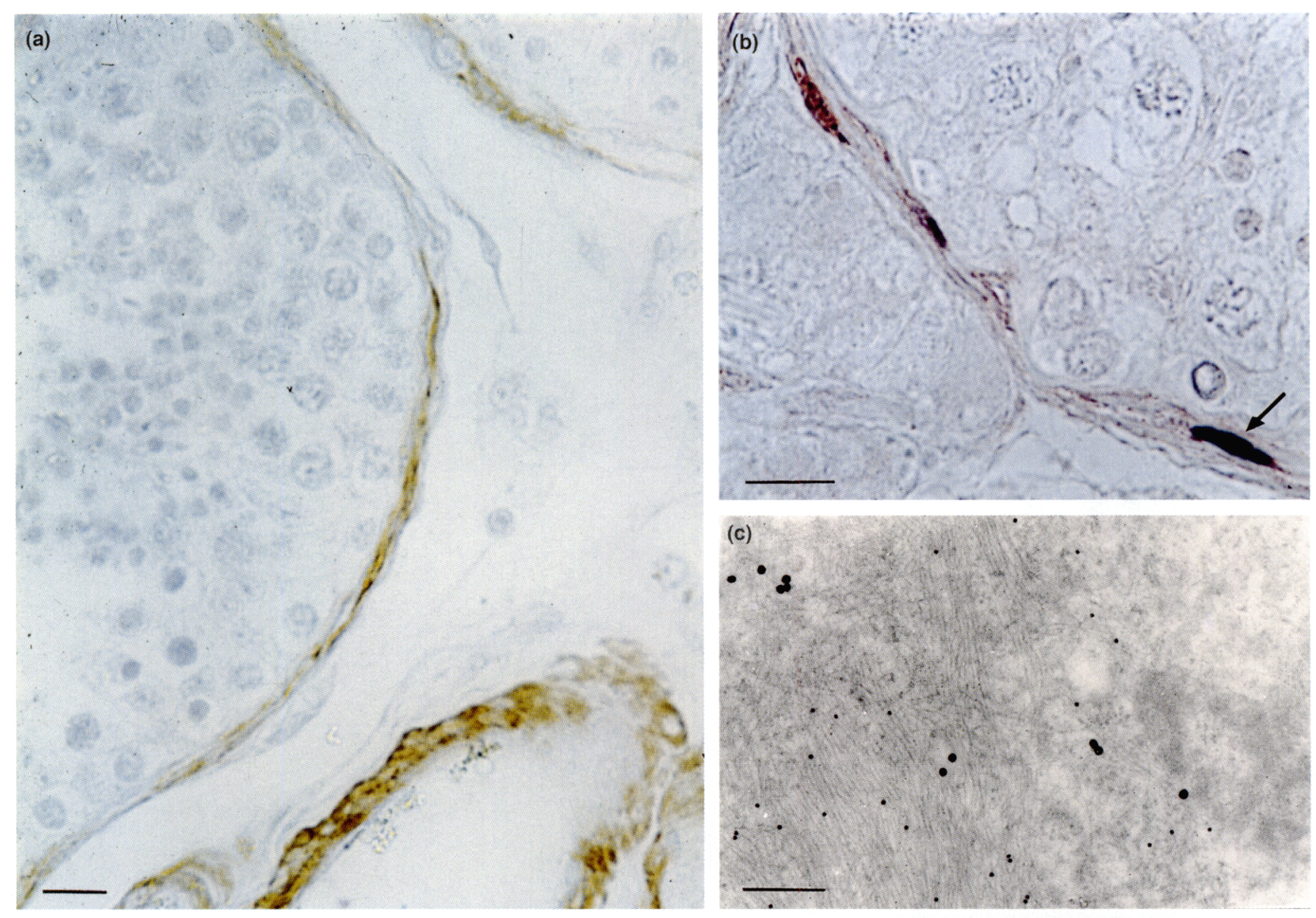

(d)

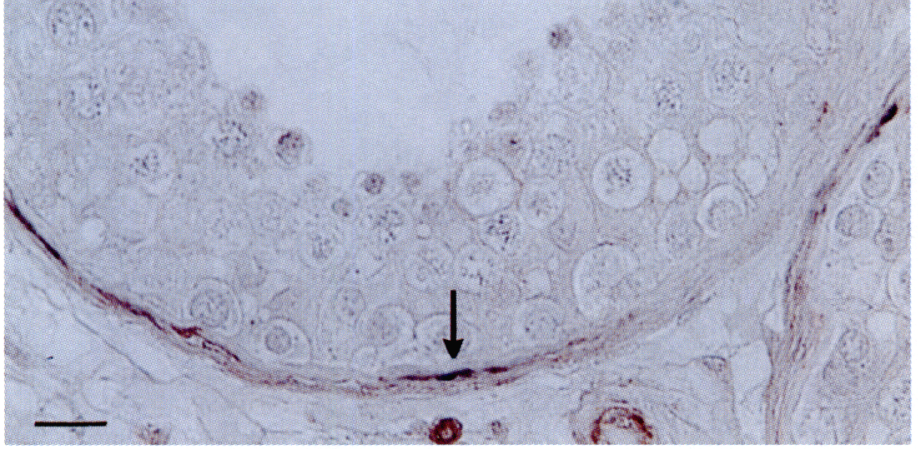

(e)

(g)
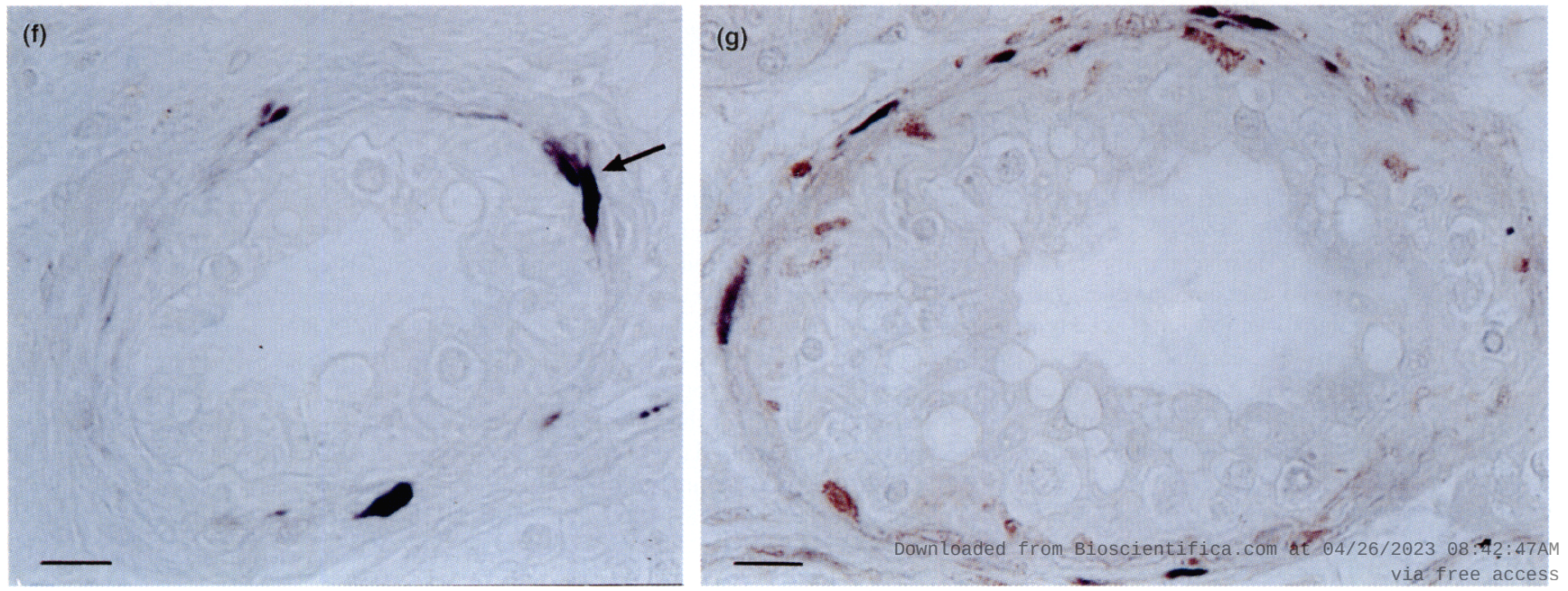
II tubules showed a moderately thickened lamina propria $(8.1-12.0 \mu \mathrm{m})$ and their spermatogenesis was usually arrested at the spermatocyte or primary spermatogonium stage. Group III tubules showed a markedly thickened lamina propria $(>12.1 \mu \mathrm{m})$ and their seminiferous epithelium consisted of spermatogonia and Sertoli cells, or Sertoli cells only. The mean $( \pm S D)$ values for each parameter measured for each tubule group were calculated from the average values for each parameter in each man.

The results from these groups were compared with those obtained from control testes that were removed 2-6h after death from 18 young men (25-39 years of age) who had died in traffic accidents or from causes other than testicular, endocrine or related diseases. The differences between mean values for each tubule-group were evaluated by the two-sample $t$ test (Fisher and Behrens' test). The above-mentioned testicular parameters (except for testicular volume) were calculated in testicular biopsies obtained from nine young-adult men (28-34 years of age) who were consulting for infertility and showed normal testicular histology at the time of testing (the cause of infertility was unconnected to the workings of the testes to ascertain whether quantitative data in postmortem testes differ from those in age-matched living men). The statistical analysis of the results showed no significant differences between control postmortem testes and control living testes.

For immunoelectron microscopy, before formaldehyde fixation, small testicular fragments $\left(1 \mathrm{~mm}^{3}\right)$ were fixed for $6 \mathrm{~h}$ at $4^{\circ} \mathrm{C}$ in a mixture of $2.5 \%(\mathrm{w} / \mathrm{v})$ paraformaldehyde and $0.5 \%$ $(\mathrm{v} / \mathrm{v})$ glutaraldehyde, buffered with $0.1 \mathrm{~mol}$ phosphate $1^{-1}$, at $\mathrm{pH}$ 7.4. Afterwards, the material was washed, dehydrated and embedded in Lowicryl K4M (EMS, Washington). Ultrathin sections were placed on drops of Tris buffer $\left(0.2 \mathrm{~mol} \mathrm{l}^{-1}\right)$ containing $0.1 \%(\mathrm{w} / \mathrm{v})$ glycine and $1 \%(\mathrm{w} / \mathrm{v}) \mathrm{BSA}$. They were then incubated for $2 \mathrm{~h}$ at room temperature with the primary antibodies at the following dilutions: actin, 1:200; vimentin, 1:50; and desmin, 1:50. After washing with Tris buffer, the sections were incubated with goat anti-mouse biotinylated $\operatorname{IgG}$ labelled with $15 \mathrm{~nm}$ gold particles (BioCell) at 1:200 dilution for $2 \mathrm{~h}$ at room temperature. After incubation with the second antibody, the sections were washed with Tris buffer and distilled water and counterstained with uranyl acetate for $20 \mathrm{~min}$ at room temperature. Double immunogold labelling for actin-desmin, actin-vimentin or desmin-vimentin was carried out in some sections. The procedure differed only from that of single immunolabelling in that, after incubation with the second antibody, the binding sites of unreacted immunoglobulins were denatured using hot paraformaldehyde vapour and a second single labelling procedure was carried out with larger gold particles $(30 \mathrm{~nm})$ (Wang and Larson, 1985). The background immunoreaction was determined in each subject and group of tubules by counting the number of immunogold particles in extracellular locations in at least 15 micrographs (at a final magnification of $\times 15000$ ) of three, non-consecutive, ultrathin sections (five micrographs per section). The intensity of background was scored as intense ( $>10$ particles per $\left.\mu \mathrm{m}^{2}\right)$, medium (2-10 particles) or low ( $<2$ particles).

The immunostaining specificity in the preparations for both the light and electron microscope was answered by analysing negative controls either omitting primary antibody or using this antibody preabsorbed with an excess of purified antigens.

\section{Results}

In control testes (Fig. 1a) and in group I tubules from elderly men (Fig. 1b), the peritubular cells form a narrow band in paraffin wax sections. In electron micrographs, from four to eight peritubular cell layers were counted. In thickened group III tubules (Fig. 1c), the lamina propria comprised (Fig. Id) an inner, homogeneous, nearly acellular band consisting of a multilayered basal lamina, which displayed occasional infoldings towards the seminiferous epithelium, and abundant collagen fibres; as well as a number of peritubular cells layers, which were more separated by collagen fibre bundles than normal tubules. The number of peritubular cells per cross-sectioned tubule, calculated on HE-stained sections, increased $(P \leq 0.05)$ from group I to group III tubules (Table 1). However, when the total number of peritubular cells per testis was calculated, no significant difference $(P \leq 0.05)$ between ageing men and controls was found (Table 2).

The results of western blot studies showed a single band, at the corresponding molecular mass, for each of the antibodies used (Fig. Ie).

Immunohistochemical study in frozen sections (Fig. 2a,b) showed positive immunostaining to actin, smooth muscle $\alpha$-actin, desmin and vimentin in the lamina propria of all tubule types and testes studied. Similar results were obtained in paraffin wax-embedded sections (Figs 2c,f, 3a,b,d,f,g, 4a,b). A comparison of both techniques revealed that immunolabelling was somewhat more intense in frozen sections. However, paraffin sections were used for the quantitative study because the transformation of peritubular cell numbers per surface area into absolute numbers per testis required the testicular

Fig. 3. (a) Desmin immunostaining in a control seminiferous tubule from the testis of a 37-year-old man; the immunoreaction (brown) indicates a uniform band around the seminiferous tubule. (The specimen was counterstained with haematoxylin-eosin). (b) Double immunostaining to actin (brown) and desmin (black) in a control testis tubule of a 34-year-old man. Most desmin-positive cells (arrow) occupy an inner location in the lamina propria. (c) Double immunolabelling to actin (using small immunogold particles) and desmin (large particles) analysed by electron microscopy in the same testis as in (b). (d) Double immunostaining to vimentin (brown) and desmin (black) in a group I tubule of a 71-year-old man. Most desmin-positive cells (arrow) occupy an inner location in the lamina propria. (e) Double immunolabelling to vimentin (small immunogold particles) and desmin (large particles) analysed by electron microscopy in a cytoplasmic projection of a peritubular cell located near the basal lamina of a group I tubule from a 74-year-old man. Small and large immunogold particles are present in the filaments. (f) Immunostaining to desmin (black) in a group III tubule of a 78-year-old man. Desmin-positive cells form a discontinuous band around the seminiferous tubule (arrow). (g) Double immunostaining to actin (brown) and desmin (black) in a group III tubule from a 78-year-old man. Isolated desmin-immunostained cells are seen among actin-positive cells. Scale bars represent $\{a, b, d, f, g) 20 \mu \mathrm{m}$ and (c, e) $0.25 \mu \mathrm{m}$. The degree of lamina propria thickening due to tubular sclerosis is $<8 \mu \mathrm{m}$ in group I tubules, $8.1-12.0 \mu \mathrm{m}$ in group II tubules and $>12.1 \mu \mathrm{m}$ in group III tubules. 

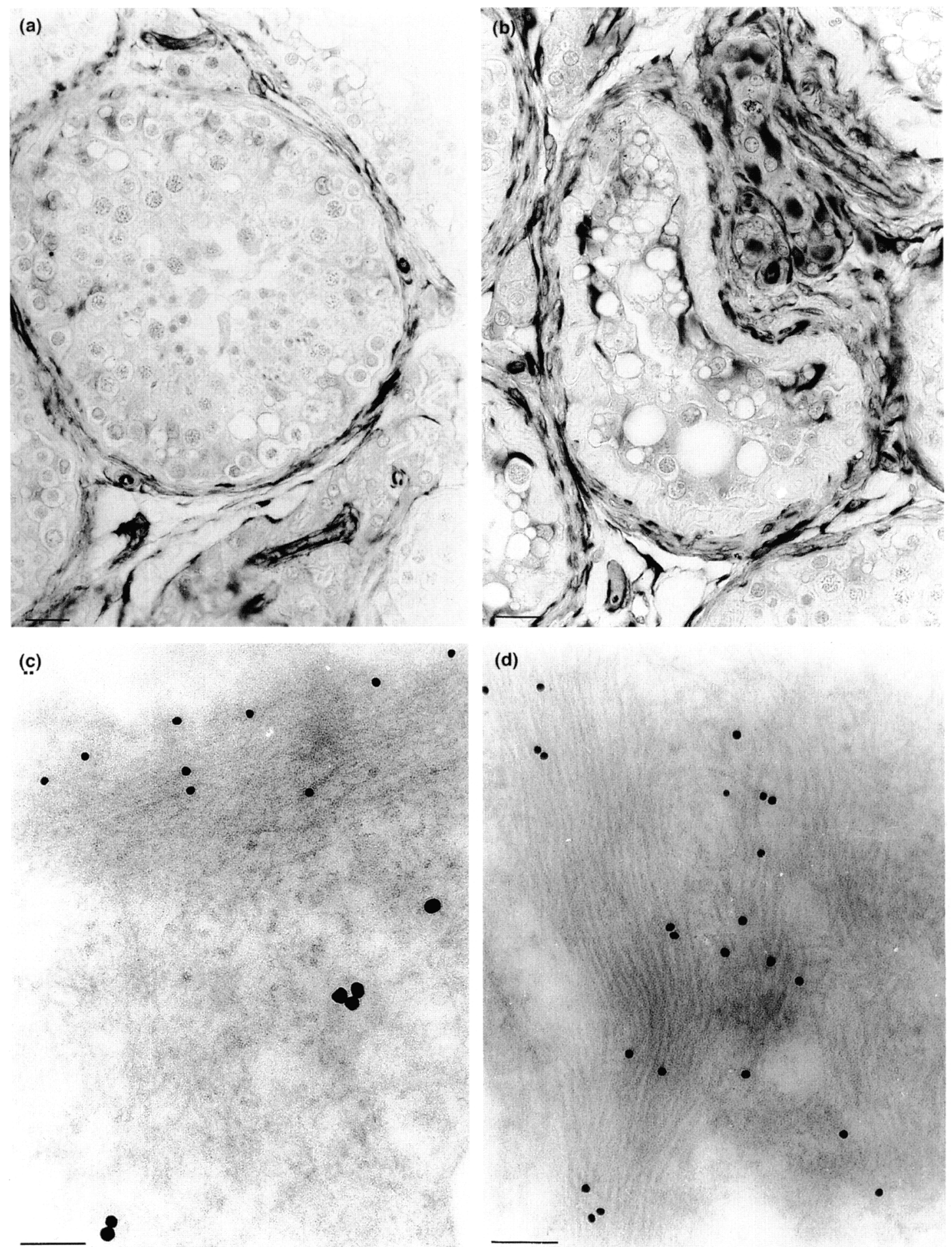

Fig. 4. (a) Vimentin immunostaining in a control seminiferous tubule from the testis of a 34-year-old man. The whole lamina propria is occupied by immunostained cells. (b) Vimentin immunostaining in a group III tubule of a 77-year-old man. Except for the inner homogeneous band, the whole lamina propria is occupied by immunostained cells. (c) Double immunolabelling to actin (small immunogold particles) and vimentin (large particles) analysed by electron microscopy in a cytoplasmic projection of a peritubular cell from a group I tubule from a 77-year-old man. Small and large immunogold particles are present in the filaments. (d) Double immunolabelling to vimentin (small immunogold particles) and desmin (large particles) analysed by electron microscopy in a cytoplasmic projection of a peritubular cell that was located in the outer layers of the lamina propria of a group I tubule from a 73-year-old man. Only small immunogold particles are seen. Scale bars represent $(a, b) 20 \mu \mathrm{m}$ and $(c, d) 0.1 \mu \mathrm{m}$. The degree of lamina propria thickening due to tubular sclerosis is $<8 \mu \mathrm{m}$ in group I tubules, $8.1-12.0 \mu \mathrm{m}$ in group II tubules and $>12.1 \mu \mathrm{m}$ in group III tubules. 
Table 3. Volume and number per pair of testes of actin-positive peritubular cells in young-adult control testes and testes from ageing men

\begin{tabular}{lccccc}
\hline $\begin{array}{l}\text { Testis } \\
\text { type }\end{array}$ & $\begin{array}{c}\text { Testicular } \\
\text { volume } \\
\left(\mathrm{cm}^{3}\right)\end{array}$ & $\begin{array}{c}\text { Volume } \\
\text { density of } \\
\text { nuclei } \\
(\%)\end{array}$ & $\begin{array}{c}\text { Total } \\
\text { nuclear } \\
\text { volume }\end{array}$ & $\begin{array}{c}\text { Average } \\
\text { nuclear } \\
\text { volume } \\
\left(\mu \mathrm{m}^{3}\right)\end{array}$ & $\begin{array}{c}\text { Total } \\
\text { number } \\
\left(\times 10^{\circ}\right)\end{array}$ \\
\hline Controls & $32.20 \pm 3.1^{\mathrm{a}}$ & $0.49 \pm 0.03^{\mathrm{a}}$ & $192 \pm 12.0^{\mathrm{a}}$ & $192 \pm 8.8^{\mathrm{a}}$ & $823 \pm 43^{\mathrm{a}}$ \\
Ageing men & $24.30 \pm 3.4^{\mathrm{b}}$ & $0.63 \pm 0.04^{\mathrm{b}}$ & $102 \pm 11.6^{\mathrm{b}}$ & $197 \pm 9.5^{\mathrm{a}}$ & $518 \pm 44^{\mathrm{b}}$ \\
\hline
\end{tabular}

For each parameter, values with different superscript letters are statistically different $(P \leq 0.05)$.

For each type of testis, 19 testes were measured.

Table 4. Volume and number per pair of testes of desmin-positive peritubular cells in young-adult control testes and testes from ageing men

\begin{tabular}{lccccc}
\hline $\begin{array}{l}\text { Testis } \\
\text { type }\end{array}$ & $\begin{array}{c}\text { Testicular } \\
\text { volume } \\
\left(\mathrm{cm}^{3}\right)\end{array}$ & $\begin{array}{c}\text { Volume } \\
\text { density of } \\
\text { nuclei } \\
(\%)\end{array}$ & $\begin{array}{c}\text { Total } \\
\text { nuclear } \\
\text { volume }\end{array}$ & $\begin{array}{c}\text { Average } \\
\text { nuclear } \\
\text { volume } \\
\left(\mu \mathrm{m}^{3}\right)\end{array}$ & $\begin{array}{c}\text { Total } \\
\text { number } \\
\left(\times 10^{\circ}\right)\end{array}$ \\
\hline Controls & $32.20 \pm 3.1^{\mathrm{a}}$ & $0.36 \pm 0.03^{\mathrm{a}}$ & $116 \pm 10.8^{\mathrm{a}}$ & $200 \pm 10.6^{\mathrm{a}}$ & $580 \pm 46^{\mathrm{a}}$ \\
Ageing men & $24.30 \pm 3.4^{\mathrm{b}}$ & $0.29 \pm 0.03^{\mathrm{b}}$ & $70.5 \pm 9.3^{\mathrm{b}}$ & $198 \pm 9.1^{\mathrm{a}}$ & $356 \pm 37^{\mathrm{b}}$ \\
\hline
\end{tabular}

For each parameter (column), values with different superscript letters are statistically different $(P \leq 0.05)$.

For each type of testis, 19 testes were measured.

parenchyma volume to be calculated, which was made using paraffin-embedded sections.

Immunolabelling with actin appeared in most peritubular cells of control testes, as well as in group I and group II tubules of elderly men (Fig. 2c,d). No apparent differences between pan-actin antibodies and anti-smooth muscle $\alpha$-actin antibodies were observed in the immunolabelling pattern of the peritubular cells. The numbers of immunogold particles per $\mu \mathrm{m}^{2}$ were: 28 in the cytoplasm, 6.3 in the nucleus and 1.8 in the extracellular matrix. Actin immunolabelling was visualized in the microfilament bundle (Fig. 2e). In group III tubules, many peritubular cells in the outermost layers showed no or scanty immunolabelling (Fig. 2f). The number of actin-immunostained cells per cross-sectioned tubule gradually decreased from group I tubules to group III tubules (Table I). The total number per testis of these cells was significantly lower $(P \leq 0.05)$ in elderly men (Table 3).

Immunostaining to desmin showed a narrow band around the seminiferous epithelium in control tubules and group I tubules of elderly men (Fig. 3a). These cells also immunoreacted to actin (Fig. 3b,c) and vimentin (Fig. 3d,e). Immunogold particles bound to desmin were seen in the filament bundles, where they were co-localized with actin-bound particles, and in isolated filaments. The numbers of desmin-bound immunogold particles per $\mu \mathrm{m}^{2}$ were: 6.7 in the cytoplasm, 1.0 in the nucleus and 0.9 in the extracellular matrix. In group II tubules and, principally, in group III tubules, immunolabelling to desmin stained isolated peritubular cells rather than a continuous band (Fig. 3f,g). The number of desmin-immunostained cells per cross-sectioned tubule gradually decreased with advancing tubular sclerosis (Table 1). The total number of these cells per testis was significantly lower $(P \leq 0.05)$ in elderly men (Table 4).

Vimentin immunolabelling was observed in most peritubular cells, even in the most peripherally placed peritubular cells, in all groups of tubules (Fig. 4a,b). Vimentin-positive cells also immunoreacted to actin (Fig. 4c). Co-localization of vimentin and desmin was observed in the innermost peritubular cell layers (Fig. $3 \mathrm{~d}, e$ ) but not in the peritubular cells located in the outermost layers (Fig. $4 \mathrm{~d}$ ). The numbers of vimentin-bound immunogold particles per $\mu \mathrm{m}^{2}$ were: 12.5 in the cytoplasm, 1.1 in the nucleus and 1.1 in the extracellular matrix. The number of vimentin-immunolabelled cells per cross-sectioned tubule increased from group I tubules to group III tubules (Table 1). However, when the total number of vimentin-positive peritubular cells per testis was calculated no significant differences between ageing men and control testes were found (Table 5).

\section{Discussion}

Previous immunohistochemical studies on the lamina propria of human seminiferous tubules have suggested that only the innermost layers of peritubular cells are true myoid cells because only these cells contain desmin filaments, whereas the outermost layers of peritubular cells are fibroblasts with vimentin filaments (Davidoff et al., 1990). The results of this study confirm that desmin-immunopositive cells are limited to the innermost portion of the human lamina propria and that all peritubular cells, including those with desmin filaments, are immunolabelled with actin and vimentin. The coexistence of desmin and vimentin in the peritubular myoid cells was 
Table 5. Volume and number per pair of testes of vimentin-positive peritubular cell in young-adult control testes and testes from ageing men

\begin{tabular}{lccccc}
\hline $\begin{array}{l}\text { Testis } \\
\text { type }\end{array}$ & $\begin{array}{c}\text { Testicular } \\
\text { volume } \\
\left(\mathrm{cm}^{3}\right)\end{array}$ & $\begin{array}{c}\text { Volume } \\
\text { density of } \\
\text { nuclei } \\
(\%)\end{array}$ & $\begin{array}{c}\text { Total } \\
\text { nuclear } \\
\text { volume }\end{array}$ & $\begin{array}{c}\text { Average } \\
\text { nuclear } \\
\text { volume } \\
\left(\mu \mathrm{m}^{3}\right)\end{array}$ & $\begin{array}{c}\text { Total } \\
\text { number } \\
\left(\times 10^{6}\right)\end{array}$ \\
\hline Controls & $32.20 \pm 3.1^{\mathrm{a}}$ & $0.48 \pm 0.03^{\mathrm{a}}$ & $155 \pm 11.7^{\mathrm{a}}$ & $195 \pm 9.2^{\mathrm{a}}$ & $814 \pm 39^{\mathrm{a}}$ \\
Ageing men & $24.30 \pm 3.4^{\mathrm{b}}$ & $0.67 \pm 0.05^{\mathrm{b}}$ & $163 \pm 12.4^{\mathrm{b}}$ & $199 \pm 10.3^{\mathrm{a}}$ & $814 \pm 46^{\mathrm{a}}$ \\
\hline
\end{tabular}

For each parameter (column), values with different superscript letters are statistically different $(P \leq 0.05)$.

For each type of testis, 19 testes were measured.

established by Virtanen et al. (1986) in rat testis cultures, and by Davidoff $e t$ al. (1990) in humans. In the present report, the coexistence of two types of intermediate filaments in peritubular cells has been demonstrated using ultrastructural double immunostaining and supports the smooth muscle immunophenotype of these cells.

Tubular sclerosis usually occurs in seminiferous tubules depleted of germ cells and is characterized by a thickening of the lamina propria due to an enlarged collagen network (Söderström, 1986). In addition, in the hyalinized lamina propria of cryptorchid testes and Klinefelter's syndrome testes, other substances such as elastin (Gotoh et al., 1987), type IV collagen and laminin (Santamaría et al., 1990) are abnormally deposited. It has also been reported that, in hyalinized tubules with different aetiologies, immunolabelling of both desmin and actin decreases whereas vimentin immunolabelling increases (Davidoff et al., 1990; Martín et al., 1992; Santamaría et al., 1992).

Present results in testes from elderly men indicate that, despite the increase in the number of peritubular cells per cross-sectioned tubule with advancing tubular sclerosis, the total number of peritubular cells per testis is maintained. This is in agreement with the data of a previous stereological study of human ageing testes reported by Johnson (1986). Present findings show that, with advancing tubular sclerosis, all the peritubular cells maintain their immunolabelling to vimentin but the peritubular cells that are most peripherally located in the lamina propria lose their actin immunolabelling, and many of the peritubular cells that immunostain to desmin lose their desmin immunolabelling. Therefore, although the total number of peritubular cells per testis does not change with tubular sclerosis, the number of peritubular myoid cells decreases markedly. This finding suggests that many of these cells evolve to peritubular fibroblast-like cells. Changes in the number of peritubular fibroblasts and myofibroblasts have been reported during fetal development of the human testis. From week 14 to week 39 of gestation, the number of peritubular fibroblasts per $\mathrm{mm}^{3}$ of testis tissue decreases while that of myofibroblasts increases. However, during this period, proliferative activity is displayed only by the fibroblasts (Jezek et al., 1996).

It is doubtful whether the lamina propria enlargement is either the result or the cause of germ-cell depletion in testes, which show complete spermatogenesis before testicular impairment. It has been postulated that the diminution of seminiferous tubule volume, caused by germ cell loss, results in the proliferation of collagen fibres around the tubules in an attempt to fill the empty space and replace the lost volume (Söderström, 1986). However, other authors assume that enlargement of the tunica propria hinders the metabolic exchange between the seminiferous epithelium and testicular interstitium, thus leading to germ cell loss and tubular atrophy (Bustos-Obregón, 1976). Tubular hyalinization in testes that are congenitally deficient in germ cells, such as those of cryptorchid men (Paniagua et al., 1990) and men with Klinefelter's syndrome (Martín et al., 1992), suggests that the hyalinization process is not secondary to germ cell loss; rather, it might be related to primary alterations either in the lamina propria itself or in Sertoli cells, since a cooperation between peritubular myoid cells and Sertoli cells has been demonstrated (Heindel and Treinen, 1989).

There have been a number of reports emphasizing a paracrine regulation of Sertoli cells by certain proteins (P-Mod-S; a non-mitogenic paracrine factor secreted by peritubular cells $(\mathrm{P})$ that modulate (Mod) Sertoli cell (S) function) that are synthesized and secreted by peritubular myoid cells (Skinner et al., 1988). Myoid cells have also been reported to secrete growth factors, such as transforming growth factors $\alpha$ (Skinner et al., 1989) and $\beta$ (Skinner and Moses, 1989; Ailenberg et al., 1990), insulin-like growth factor I (Cailleau et al., 1990), and activin-A (de Winter et al., 1994). The loss of myoid characteristic of peritubular cells with advancing tubular sclerosis suggests that these cells are involved in tubular hyalinization. If peritubular cells regulate the deposit of collagen and elastic fibres and amorphous ground substance (Tung and Fritz, 1987), alterations in this type of cell might in turn alter the lamina propria matrix. The thickening and hyalinization of the lamina propria may hamper the relationships between the myoid cells that are still present and the Sertoli cells; this may contribute to the observed alterations in Sertoli cells resulting from different causes of tubular atrophy (Heindel and Treinen, 1989), including ageing testes (Paniagua et al., 1987b), and, subsequently, lead to impairment of spermatogenesis.

On the other hand, it has been shown that the Sertoli cell modulates several morphological and functional aspects of the myoid cells, such as their differentiation in vitro (Tung and Fritz, 1987). With the thickening of the lamina propria, the peritubular cells located in its innermost portion remain under the influence of the Sertoli cells and thus maintain their desmin immunolabelling. The peritubular cells in the outermost layers 
lose their myoid cell characteristics because the ability of Sertoli cells to regulate them decreases. In addition, a primary alteration in the Sertoli cells would also be the cause of myoid cell alterations.

Myoid cell impairment might also be secondary to the Leydig cell impairment reported in ageing testes (Paniagua et al., 1986), since androgens (principally testosterone) modulate peritubular myoid cell secretion (Carreau et al., 1994). Leydig cell function is also modulated by the Sertoli cell (Janecki et al., 1985), and the reduced activity of $17 \alpha$ hydroxylase in testes with hyalinized tubules (Fredricsson et al., 1989) has been attributed to the lamina propria enlargement that hinders the passage of Sertoli cell factors to Leydig cells.

This work was partially supported by grants from the Dirección General de Investigación Científica y Técnica, y Comunidad Autónoma de Madrid, Spain.

\section{References}

Ailenberg M, Tung PS and Fritz IB (1990) Transforming growth factor- $\beta$ elicits shape changes and increases contractility of testicular peritubular cells Biology of Reproduction 42 499-509

Bustos-Obregón EL (1976) Ultrastructure and function of the lamina propria of mammalian seminiferous tubules Andrologia 8 179-185

Cailleau J, Vermeire S and Verhoeven G (1990) Independent control of the production of insulin-like growth factor $\mathrm{I}$ and its binding protein by cultured testicular cells Molecular and Cellular Endocrinology 69 79-89

Carreau S, Foucault P and Drosdowsky MA (1994) La cellule de Sertoli: aspects fonctionnels compareés chez le rat, le porc et l'homme annales d'Endocrinoloyie (Paris) 55 203-220

Davidoff MS, Breucker H, Holstein AF and Seidel K (1990) Cellular architecture of the lamina propria of human seminiferous tubules Cell and Tissue Research $262253-261$

Decensi AU, Guarneri D and Marroni P (1989) Evidence for testicular impairment after long-term treatment with a luteinizing hormone-releasing hormone agonist in elderly men Journal of Urology 142 1235-1238

de Kretser DM, Kerr JB and Paulsen CA (1975) The peritubular tissue in the normal and pathological human testis: an ultrastructural study Biology of Reproduction 12 317-324

de Winter JP, Vanderstichele HMJ, Verhoeven G, Timmerman MA, Wessenling JG and de Jong FH (1994) Peritubular myoid cells from immature rat testes secrete activin-A and express activin receptor type II in vitro. Endocrinology $135739-767$

Fredricsson B, Carlström K and Plöen L (1989) Steroid metabolism and morphologic features of the human testis Joumal of Andrology 10 43-49

Gotoh M, Miyake K and Mitsua H (1987) Elastic fibers in tunica propria of undescended and contralateral scrotal testes from cryptorchid patients Urology 30 359-363

Heindel JJ and Treinen KA (1989) Physiology of the male reproductive system: endocrine, paracrine and autocrine regulation Toxicologic Pathology 17 411-445

Holstein AF, Maekawa M, Nagano T and Davidoff MS (1996) Myofibroblasts in the lamina propria of human seminiferous tubules are dynamic structures of heterogeneous phenotype Archives of Histology and Cytology 59 109-125

Hsu SM and Soban E (1982) Colour modification of diaminobenzidine DAB precipitation by metallic ions and its application to double immunohistochemistry Journal of Histochemistry and Cytochemistry 30 1079-1082

Hsu SM, Reiner L and Fanger H (1981) Use of avidin-biotin peroxidase complex $A B C$ in immunoperoxidase technique: a comparison between $A B C$ and unlabeled antibody PAP procedures Journal of Histochemistry and Cytochemistry 29 577-580

Janecki A, Jabubokiak and Lukaszyl A (1985) Stimulatory effect of Sertoli cell secretory products on testosterone secretion by purified Leydig cells in primary culture Molecular and Cellular Endocrinology 42 235-243
Jezek D, Hittmair A and Rogatsch H (1996) Lamina propria of sex cords in human fetal testis: an immunological and stereological study Anatomy and Embryology $193181-190$

Johnson L (1986) Spermatogenesis and aging in the human Journal of Andrology 7 331-354

Kohnen G, Castellucci M, Hsi BL, Yeh CJ and Kaufmann P (1995) The monoclonal antibody GB 42 - a useful marker for the differentiation of myofibroblasts Cell and Tissue Research 281 231-242

Krenács T, Krenács L, Bozóky B and Iványi B (1990) Double and triple immunocytochemical labelling at the light microscope level in histopathology Histochemical journal 22 530-536

Longtine JA, Pincus GS, Fujiwara K and Corson JM (1985) Immunohistochemical localization of smooth muscle myosin in normal human tissues Journal of Histochemistry and Cytochemistry 33 179-184

Maekawa M, Kamimura K and Nagano T (1996) Peritubular myoid cells in the testis: their structure and function Archives of Histology and Cytology 59 $1-13$

Martín R, Santamaría L, Nistal M, Fraile B and Paniagua R (1992) The peritubular myofibroblasts in the testes from normal men and men with Klinefelter's syndrome: a quantitative, ultrastructural, and immunohistochemical study Joumal of Pathology 168 59-66

Paniagua R, Amat P, Nistal M and Martin A (1986) Ultrastructure of Leydig cells in human ageing testes Journal of Anatomy 146 173-183

Paniagua R, Martin A, Nistal M and Amat P (1987a) Testicular involution in elderly men: comparison of histologic quantitative studies with hormone patterns Fertility and Sterility $47671-679$

Paniagua R, Nistal M, Amat P, Rodríguez MC and Martín A (1987b) Seminiferous tubule involution in elderly men Biology of Reproduction 36 939-947

Paniagua R, Martínez-Onsurbe P, Santamaría L, Sáez FJ, Amat P and Nistal M (1990) Quantitative and ultrastructural alterations in the lamina propria and Sertoli cells in human cryptorchid testes International Journal of Andrology 13 $470-487$

Santamaría L, Martínez-Onsurbe P, Paniagua R and Nistal M (1990) Laminin, type IV collagen, and fibronectin in normal and cryptorchid human testes: an immunohistochemical study International Journal of Andrology 13 135-146

Santamaria L, Martín R, Nistal M and Paniagua R (1992) The peritubular myoid cells in the testes from men with varicocele: an ultrastructural, immunohistochemical and quantitative study Histopathology $21423-433$

Sapino A, Pagani A and Godano A (1987) Effects of estrogens on the testis of transsexuals: a pathological and immunocytochemical study Virchows Archiv A: Pathological Anatomy and Histopathology 411 409-414

Skinner MK and Moses HL (1989) Transforming growth factor-beta produced by testicular peritubular cells and Sertoli cells Journal of Biological Chemistry $26011874-11883$

Skinner MK, Fetterolf PM and Anthony CT (1988) Purification of a paracrine factor, P-Mo-S, produced by testicular peritubular cells that modulates Sertoli cell function Biology of Reproduction 40 811-823

Skinner MK, Takacs K and Coffey RJ (1989) Cellular localization of transforming growth factor-alpha gene expression and action in the seminiferous tubule: peritubular cell-Sertoli cell interactions Endocrinology 124 845-854

Söderström KO (1986) Tubular hyalinization in human testis Andrologia 18 97-103

Towbin H, Staehlin T and Gordon J (1979) Electrophoretic transfer of proteins from polyacrylamide gels to nitrocellulose sheets: procedure and some applications Proceedings of the National Academy of Sciences USA 76 43504354

Tung PS and Fritz IB (1987) Morphogenetic restructuring and formation of basement membranes by Sertoli cells and testis peritubular cells in coculture: inhibition of the morphogenetic cascade by cyclic AMP derivatives and by blocking direct cell contact Developmental Biology 123 119-134

Virtanen I, Kallajoki M, Narvanen O, Paranko J, Thornell LE, Miettinen M and Lehto VP (1986) Peritubular myoid cells of humans and rat testis are smooth muscle cells that contain desmin-type intermediate filaments Anatomical Record 215 10-20

Wang Bl and Larson LI (1985) Simultaneous antigens by indirect immunofluorescence or immunogold staining: novel light and electron microscopical double and triple staining method implying primary antibodies from the same species Histochemistry 83 47-56 